\title{
IUMRS Seeks Nominees for 2009 Sōmiya Award on International Collaboration \\ www.iumrs.org
}

The International Union of Materials Research Societies (IUMRS) is seeking nominations for the Somiya Award, which recognizes research on real materials conducted by a research team whose members are drawn from at least two continents. The submission deadline is May 1, 2009.

Sōmiya Award recipients are selected by the IUMRS Commission on Awards. The recipient(s) receive an award commemorating the occasion and free registration to the annual IUMRS International Conference where they present their work. This year the conference will be held at the 11th IUMRS International Conference on Advanced Materials (IUMRS-ICAM 2009), September 20-25, 2009 in Rio de Janeiro, Brazil.

The following criteria are used by the Commission on Awards for selection:

- the team to be honored must have collaborated across at least two conti- nents (e.g., North America, Europe, Asia, Australia) some time during the last decade;

- the collaborative work must be of the highest quality and well recognized by the international materials community; and

- the impact on technology or society is also a major factor.

The annual Sōmiya Award is named in honor of Shigeyuki Sōmiya, Emeritus Professor of the Tokyo Institute of Technology, and later Dean at Teikyo University of Science and Engineering. Sōmiya has received the MRS Medal and the Japanese Scientific Academic Award.

Sōmiya spent his post-graduate years in the United States and embarked on a series of collaborative research and exchange visits in many countries, starting in 1969 with the U.S.-Japan Workshop in Ceramics-the first in materials science. He also actively pursued joint work with colleagues in Europe, and brought many international materials gatherings to Japan.

The 2007 Sōmiya Award for International Collaboration in Materials Research was awarded to an American-Belgian research team led by Ivan K. Schuller of The University of California, San Diego and Yvan Bruynseraede of Katholieke Universiteit Leuven for their investigation of "Structure and Physical Properties of Superconducting and Magnetic Nanostructures."

Information about the award and nomination forms are available at www.iumrs. org and must be received at the IUMRS Headquarters by May 1, 2009.

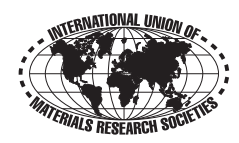

\section{MRS Invites Nominations for the Von Hippel Award, Turnbull Lectureship, and MRS Medal}

The Materials Research Society is seeking nominations for the Von Hippel Award, the Turnbull Lectureship, and the MRS Medal. The deadline for nominations is April 1, 2009. These awards will be presented at the 2009 MRS Fall Meeting, November 30-December 4, in Boston.

The MRS awards program recognizes outstanding contributors to the progress of materials research. Nomination forms and details about eligibility and nomination criteria are available from the Materials Research Society Web site at www. mrs.org/awards.

\section{Von Hippel Award Acknowledges Outstanding Interdisciplinary Work in Materials Research}

The Von Hippel Award, first presented to Arthur R. von Hippel, whose interdisciplinary and pioneering research typified the spirit of the award, is the Society's highest honor. The recipient is recognized for brilliance and originality of intellect, combined with vision that transcends the boundaries of conventional scientific disciplines. The award includes a $\$ 10,000$ cash prize, honorary membership in MRS, and a unique trophy - a mounted ruby laser crystal, symbolizing the many-faceted nature of materials research.

\section{Turnbull Lectureship Honors Career of an Outstanding Researcher and Communicator}

The David Turnbull Lectureship recognizes the career of a scientist who has made outstanding contributions to understanding materials phenomena and properties through research, writing, and lecturing, as exemplified by the life work of David Turnbull. While honoring the accomplishments of the recipient, the Turnbull Lectureship is intended to support and enrich the materials research community.
The recipient will give a technical lecture of broad appeal at a designated session of the 2009 MRS Fall Meeting. The Turnbull Lecturer will receive a $\$ 5,000$ honorarium and a citation plaque, along with a travel allowance for speaking engagements throughout the year.

\section{MRS Medal Recognizes Recent Discovery or Advancement in Materials Science}

The MRS Medal offers public and professional recognition of an exceptional achievement by an individual in materials research. The Medal is awarded for a specific outstanding recent discovery (approximately last 10 years) or advancement that is expected to have a major impact on the progress of any materialsrelated field.

The award consists of a $\$ 5,000$ cash prize, an engraved and mounted medal, and a citation certificate. 